\title{
ПРАВОВОЕ РЕГУЛИРОВАНИЕ ПРИМЕНЕНИЯ СОТРУДНИКАМИ ПОЛИЦИИ ФИЗИЧЕСКОЙ СИЛЫ, СПЕЦИАЛЬНЫХ СРЕДСТВ И ОГНЕСТРЕЛЬНОГО ОРУЖИЯ
}

马 ля борьбы с преступностью, обеспечения правопорядка сотрудники полиции наделяются дополнительными полномочиями по применению фризической силы, специальных средств и огнестрельного оружия. Это меры специального характера, поэтому их реализация должна основываться на строго правовой основе и при наличии четких оснований.

Необходимо сказать, что применение огнестрельного оружия в отличие от других мер административного пресечения всегда носит активный характер, в то время как использование фризической силы и специальных средств в некоторых случаях происходит в форме пассивного сопротивления. В частности, специальные средства применяются для принудительной остановки автотранспорта либо для препятствования движения толпы ${ }^{1}$. Сотрудник полиции при применении физической силы, специальных средств или огнестрельного оружия действует с учетом создавшейся обстановки, характера и степени опасности действий лиц, в отношении которых применяются физическая сила, специальные средства или огнестрельное оружие, характера и силы оказываемого ими сопротивления. При этом сотрудник полиции обязан стремиться к минимизации любого ущерба².

Сотрудник полиции обязан оказать гражданину, получившему телесные повреждения в результате применения фризической силы, специальных средств или огнестрельного оружия, первую помощь, а также принять меры по предоставлению ему медицинской помощи в возможно короткий срок. О причинении гражданину телесных повреждений в результате применения сотрудником полиции фризической силы, специальных средств или огнестрельного оружия полиция

\footnotetext{
${ }^{1}$ См.: Фролов В.В. Административное пресечение как мера административно-правового принуждения. - Томск, $2001 /$ http://5ballov.qip.ru/referats/preview/30710

2 См.: Кокорев А.Н. Меры административного пресечения, применяемые органами внутренних дел: автореф. дис. ... канд. юрид. наук. - М., 2007. - С. 10.
}

в возможно короткий срок, но не более 24 часов уведомляет близких родственников или близких лиц гражданина. О каждом случае причинения гражданину ранения либо наступления его смерти в результате применения сотрудником полиции физической силы, специальных средств или огнестрельного оружия уведомляется прокурор в течение 24 часов. Сотрудник полиции обязан по возможности сохранить без изменения место совершения преступления, административного правонарушения, место происшествия, если в результате применения им фризической силы, специальных средств или огнестрельного оружия гражданину причинено ранение либо наступила его смерть.

О каждом случае применения фризической силы, в результате которого причинен вред здоровью гражданина или причинен материальный ущерб гражданину либо организации, а также о каждом случае применения специальных средств или огнестрельного оружия сотрудник полиции обязан сообщить непосредственному начальнику либо руководителю ближайшего территориального органа или подразделения полиции и в течение 24 часов с момента их применения представить соответствующий рапорт.

Сотрудник полиции имеет право лично или в составе подразделения (группы) применять фризическую силу, в том числе боевые приемы борьбы, если несиловые способы не обеспечивают выполнения возложенных на полицию обязанностей, в следующих случаях:

- для пресечения преступлений и административных правонарушений;

- для доставления в служебное помещение территориального органа или подразделения полиции, в помещение муниципального органа, в иное служебное помещение лиц, совершивших преступления и административные правонарушения, и задержания этих лиц;

- для преодоления противодействия законным требованиям сотрудника полиции. 
Говоря о специальных средствах, то сотрудник полиции имеет право лично или в составе подразделения (группы) применять специальные средства в следующих случаях:

- для отражения нападения на гражданина или сотрудника полиции;

- для пресечения преступления или административного правонарушения;

- для пресечения сопротивления, оказываемого сотруднику полиции;

- для задержания лица, застигнутого при совершении преступления и пытающегося скрыться;

- для задержания лица, если это лицо может оказать вооруженное сопротивление;

- для доставления в полицию, конвоирования и охраны задержанных лиц, лиц, заключенных под стражу, подвергнутых административному наказанию в виде административного ареста, а также в целях пресечения попытки побега, в случае оказания лицом сопротивления сотруднику полиции, причинения вреда окружающим или себе;

- для освобождения насильственно удерживаемых лиц, захваченных зданий, помещений, сооружений, транспортных средств и земельных участков;

- для пресечения массовых беспорядков и иных противоправных действий, нарушающих движение транспорта, работу средств связи и организаций;

- для остановки транспортного средства, водитель которого не выполнил требование сотрудника полиции об остановке;

- для выявления лиц, совершающих или совершивших преступления или административные правонарушения;

- для защиты охраняемых объектов, блокирования движения групп граждан, совершающих противоправные действия.

Сотруднику полиции запрещается применять специальные средства:

- в отношении женщин с видимыми признаками беременности, лиц с явными признаками инвалидности и малолетних лиц, за исключением случаев оказания указанными лицами вооруженного сопротивления, совершения группового либо иного нападения, угрожающего жизни и здоровью граждан или сотрудника полиции;

- при пресечении незаконных собраний, митингов, демонстраций, шествий и пикетиро- ваний ненасильственного характера, которые не нарушают общественный порядок, работу транспорта, средств связи и организаций.

Специальные средства применяются с учетом следующих ограничений:

- не допускается нанесение человеку ударов палкой специальной по голове, шее, ключичной области, животу, половым органам, в область проекции сердца;

- не допускается применение водометов при температуре воздуха ниже нуля градусов Цельсия;

- не допускается применение средств принудительной остановки транспорта в отношении транспортных средств, предназначенных для перевозки пассажиров (при наличии пассажиров), транспортных средств, принадлежащих дипломатическим представительствам и консульским учреждениям иностранных государств, а также в отношении мотоциклов, мотоколясок, мотороллеров и мопедов; на горных дорогах или участках дорог с ограниченной видимостью; на железнодорожных переездах, мостах, путепроводах, эстакадах, в туннелях;

- установка специальных окрашивающих средств на объекте осуществляется с согласия собственника объекта или уполномоченного им лица, при этом сотрудником полиции принимаются меры, исключающие применение указанных средств против случайных лиц.

Применение водометов и бронемашин осуществляется по решению руководителя территориального органа с последующим уведомлением прокурора в течение 24 часов.

Говоря о применении огнестрельного оружия, то следует особо подчеркнуть следующее. В научной литературе в свое время отмечалось «... являясь фризическим средством пресечения неправомерных действий, огнестрельное оружие представляет собой такое техническое устройство, результат применения которого, как указывали еще отечественные юристы начала нынешнего века, не может быть учтен заранее 3 .

Применение оружия может дать непредсказуемые фрактические последствия: от легкой раны до смерти лица. И в том, и в другом случае ре-

\footnotetext{
${ }^{3}$ См.: Гаген В.А. Учебник административного права. - Ростовн/Д, 1916. - С. 8 // Цитируется по работе А.И. Елистратова Административное право РСФСР. - Л., 1925. - С. 78.
} 
шающую роль могут сыграть случайные факторы: окружающая обстановка, почва, дорожное покрытие и даже конструктивные особенности табельного оружия, которым оснащена полиция ${ }^{4}$.

Одним из характерных признаков применения огнестрельного оружия является реализация данной меры в сверхэкстремальных, стрессовых условиях. Причем стресс вызывают как сами общественно опасные действия правонарушителя, так и осознание возможности причинения серьезного вреда в результате выстрела, а, кроме того - и боязнь ответственности за причиненный ущерб и невыполнение служебного долга. По мнению авторов, исследовавших особенности психических процессов сотрудников полиции в ситуации действия оружием, данная мера принуждения всегда реализуется в экстремальных условиях и характеризуется особым напряжением психологических сил лица 5 .

Сотрудник полиции имеет право лично или в составе подразделения (группы) применять огнестрельное оружие в следующих случаях:

- для защиты другого лица либо себя от посягательства, если это посягательство сопряжено с насилием, опасным для жизни или здоровья;

- для пресечения попытки завладения огнестрельным оружием, транспортным средством полиции, специальной и боевой техникой, состоящими на вооружении (обеспечении) полиции;

- для освобождения заложников;

- для задержания лица, застигнутого при совершении деяния, содержащего признаки тяжкого или особо тяжкого преступления против жизни, здоровья или собственности, и пытающегося скрыться, если иными средствами задержать это лицо не представляется возможным;

- для задержания лица, оказывающего вооруженное сопротивление, а также лица, отказывающегося выполнить законное требование о сдаче находящихся при нем оружия, боеприпасов, взрывчатых веществ, взрывных устройств, ядовитых или радиоактивных веществ;

\footnotetext{
${ }^{4}$ См.: Фролов В.В. Административное пресечение как мера административно-правового принуждения. - Томск, 2001 / http://5ballov.qip.ru/referats/preview/30710

${ }^{5}$ См.: Хвастунов А.А., Колюхов В.Г. Применение оружия как экстремальная ситуация деятельности сотрудников органов внутренних дел. - Домодедово, 1994. - С. 91.
}

- для отражения группового или вооруженного нападения на здания, помещения, сооружения и иные объекты государственных и муниципальных органов, общественных объединений, организаций и граждан;

- для пресечения побега из мест содержания под стражей подозреваемых и обвиняемых в совершении преступлений или побега из-под конвоя лиц, задержанных по подозрению в совершении преступления, лиц, в отношении которых применена мера пресечения в виде заключения под стражу, лиц, осужденных к лишению свободы, а также для пресечения попытки насильственного освобождения указанных лиц.

Сотрудник полиции также имеет право применять огнестрельное оружие:

- для остановки транспортного средства путем его повреждения, если управляющее им лицо отказывается выполнить неоднократные требования сотрудника полиции об остановке и пытается скрыться, создавая угрозу жизни и здоровью граждан;

- для обезвреживания животного, угрожающего жизни и здоровью граждан и (или) сотрудника полиции;

- для разрушения запирающих устройств, элементов и конструкций, препятствующих проникновению в жилые и иные помещения;

- для производства предупредительного выстрела, подачи сигнала тревоги или вызова помощи путем производства выстрела вверх или в ином безопасном направлении.

Запрещается применять огнестрельное оружие с производством выстрела на поражение в отношении женщин, лиц с явными признаками инвалидности, несовершеннолетних, когда их возраст очевиден или известен сотруднику полиции, за исключением случаев оказания указанными лицами вооруженного сопротивления, совершения вооруженного или группового нападения, угрожающего жизни и здоровью граждан или сотрудника полиции. Сотрудник полиции не имеет права применять огнестрельное оружие при значительном скоплении граждан, если в результате его применения могут пострадать случайные лица. 


\section{Библиографический список:}

1. Гаген В.А. Учебник административного права. - Ростов-н/Д., 1916.

2. Елистратов А.И. Административное право РСФСР. - Л., 1925.

3. Кокорев А.Н. Меры административного пресечения, применяемые органами внутренних дел: автореф. дис. ... канд. юрид. наук. - М., 2007.

4. Хвастунов А.А., Колюхов В.Г. Применение оружия как экстремальная ситуация деятельности сотрудников органов внутренних дел. - Домодедово, 1994.

5. Фролов В.В. Административное пресечение как мера административно-правового принуждения. Томск, 2001 / http://5ballov.qip.ru/referats/preview/30710 